\title{
Helioscope Based Design of A MWp Solar PV Plant on a MARSHY LAND OF BANGLADESH AND PREDICTION OF PLANT PERFORMANCE WITH THE VARIATION OF TILT ANGLE
}

\author{
Md.Shahin Ali, Nazmun Nahar Rima, Md.Iftekhar Hossain Sakib and Muhammad Fayyaz Khan
}

\begin{abstract}
HelioScope is the solar industry's leading software platform for designing and analysis performance of a solar plant for a medium to large solar PV plants. Folsom Labs developed HelioScope, an advanced solar PV design software for medium to large solar PV plant. In this paper, the authors have designed a grid tied solar PV based power plant for a sample area of around 20 acre in the district of Rajshahi, Bangladesh. The main feature of the HelioScope software is the efficient layout of the arrays and blocks of the panels once the location of the area is set in the software. Also, authors have tried to focus on the variation of the solar PV output with the variation of the tilt angle of the panels. Normally, in a particular area, tilt angle is adjusted according to the latitude angle of the concerned area. In densely populated countries like Bangladesh, scarcity of land for solar PV generation is extremely acute although there is abundant solar energy available for setting up of solar PV plants. By increasing the tilt angle, substantial area can be saved which can be utilized to set up more numbers of solar panels when compared to the area required with the normal tilt angle which ultimately enhances the generation capacity of the plant and reduce the cost. Solar PV generation for the sample area has been determined for different tilt angles and it has been shown that the solar PV generation increases substantially with the increase of the tilt angle thereby reducing the cost of energy for the sample area under consideration.
\end{abstract}

Index Terms - HelioScope, Folsom, PV, Tilt angle, Latitude, COE.

This paper was received on 22 April 2019, accepted on 20 August 2019. This work was supported by Green University of Bangladesh (GUB).

Md. Shahin Ali is with Dept. of Electrical and Electronic Engineering of GUB, mail: shahinali830 @gmail.com

Nazmun Nahar Rima is with Dept. of Electrical and Electronic Engineering of GUB, mail: nazmunrima.95@gmail.com

Md. Iftekhar Hossain Sakib is with Dept. of Electrical and

Electronic Engineering of GUB, mail: ftekharhossain2@gmail.com

Md. Fayyaz Khan is with Dept. of Electrical and Electronic

Engineering of GUB, mail: fyk@green.edu.bd

\section{INTRODUCTION}

$\mathrm{H}$ elioScope software is basically a web based software where initial input required is the longitude and latitude of the area or alternatively if the name of the area is properly inserted in the designated window, the area map of the concerned land is downloaded automatically. Also, choosing the proper type of panels and inverters, the complete layout of the plant is automatically generated with all the relevant data like power output, system loss, energy to grid, number of modules and inverters, grouping of panels etc.

In a nutshell, it can be stated that this software automatically produces the layout design of major components once the co-ordinates of the sample area are specified together with area map, panel specifications, inverter type, etc.

Our selected area is Nirmal char, a marshy land which is situated in the Rajshahi district of Bangladesh with latitude and longitude of $24.36^{\circ} \mathrm{N}$ and is $88.62^{\circ} \mathrm{E}$ respectively. We considered the total area around 20.5 Acres. Here the location latitude is 24.5 due south which is considered the location tilt angle of Rajshahi area [1]. Now-a-days PV systems are becoming more and more complicated, and using multiple technologies - HelioScope is the only tool that can model these complex arrays [2]. There are lots of software tools available to help renewable energy engineers evaluate performance and design a photovoltaic system. In the recent time, PV System has become the industry standard, estimating energy production that accounts for losses due to weather and climate, shading, wiring, component efficiencies, panel mismatches, and aging, and providing recommendations for equipment and array layout. But HelioScope, a new program introduced by Folsom Labs, includes all the features of PV System and adds the design functionality of AutoCad, allowing designers to do a complete design in one package [3]. The most challenging part of a solar PV based software is the efficient combination of panels to make an array and also proper choice of inverter, combiner box and other accessories. 


\section{DESIGN SEQUENCE BY HELIOSCOPE}

First we put the location address of the designated area. Then specify a PV module, and chooses an inverter model. Using Google map to find the location and import its 3D layout into Sketch Up, a free drawing program. Based on that 3D model, HelioScope will perform its shading analysis [4]. Then based on all information, HlioScope gives a recommended PV panel layout and provides a detail information about wiring diagram, including the exact placement of panels, inverters, and other equipment. Also HelioScope shows us the annual and monthly production of irradiance and energy supplied to grid, required number of modules and inverters, total power generation and performance ratio of the whole system [5].

\section{PV PLANT DESIGN FOR THE SAMPLE AREA}

By introducing information about area and choosing the panel, inverter model type, HelioScope generates a layout of the plant as shown in the figure1. The beauty of the software is that the number of location of inverters, combiner box, series-parallel combination of panel etc. are displayed through 3-D AutoCAD tools. In the sample area that has been chosen, an area of around 20.5 acres has been selected that will generate around $7 \mathrm{MWp}$ of electricity during sun-shine hours under standard irradiance. The area is located at a distance of $3 \mathrm{~km}$ from Rajshahi city and there is a good road network to reach to the area. In the design, $325 \mathrm{Wp}$ panels are chosen and the total number of panels required is 26,906 with 287 inverters and Single line diagram of the plant is shown in the figure 1 .

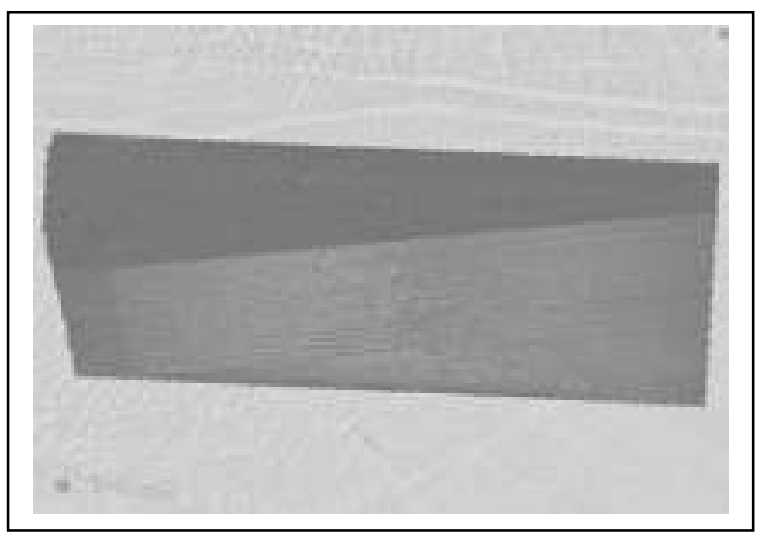

Fig. 1. Layout design for the system

\section{OUTPUT VARIATION WITH TILT ANGLE}

In our analysis we observed that when we increased the tilt angle compared to the standard tilt angle, then the production of energy, power generation, required number of modules and inverters also increased but at the same time the performance ratio of the system slightly decreased [6]. On the other hand, when we decreased the tilt angle compare to the standard tilt angle, then all the previous mention results also decreased but the performance ratio has increased [7]. The variation of the tilt angle and the results of energy to grid, power generation, required number of modules and inverters are given in table 1.

TABLE I

Production OF ENERGY TO GRID AND POWER GENERATION FOR DIFFERENT TILT ANGLE

\begin{tabular}{|c|c|c|c|c|c|}
\hline $\begin{array}{l}\text { Tilt } \\
\text { Angle }\end{array}$ & $\begin{array}{l}\text { Energy to } \\
\text { Grid } \\
\text { (KWh) } \\
\text { yearly }\end{array}$ & $\begin{array}{l}\text { No. of } \\
\text { Modul } \\
\text { es } \\
(320)\end{array}$ & $\begin{array}{l}\text { Power } \\
\text { (MW) }\end{array}$ & $\begin{array}{l}\text { Annual } \\
\text { Product } \\
\text { ion }\end{array}$ & $\begin{array}{l}\text { Perform } \\
\text { ance } \\
\text { Ratio }\end{array}$ \\
\hline 22 & $\begin{array}{l}13,333,20 \\
0\end{array}$ & 26,725 & 8.55 & $\begin{array}{l}13.33 \\
\text { GWh }\end{array}$ & $80.5 \%$ \\
\hline $\begin{array}{l}23.5 \\
\text { (Stan } \\
\text { dard) }\end{array}$ & $\begin{array}{l}13,429,80 \\
0\end{array}$ & 26,906 & 8.61 & $\begin{array}{l}13.43 \\
\text { GWh }\end{array}$ & $80.3 \%$ \\
\hline $\begin{array}{l}24.5 \\
\text { (Loca } \\
\text { tion } \\
\text { Tilt) }\end{array}$ & $\begin{array}{l}13,488,40 \\
0\end{array}$ & 27,031 & 8.65 & $\begin{array}{l}13.49 \\
\text { GWh }\end{array}$ & $80.2 \%$ \\
\hline 26 & $\begin{array}{l}13,476,80 \\
0\end{array}$ & 27,228 & 8.71 & $\begin{array}{l}13.48 \\
\text { GWh }\end{array}$ & $79.5 \%$ \\
\hline 28 & $\begin{array}{l}13,608,40 \\
0\end{array}$ & 27,522 & 8.81 & $\begin{array}{l}13.61 \\
\text { GWh }\end{array}$ & $79.4 \%$ \\
\hline
\end{tabular}

For the effective comparison of results, additional tilt angles of 23.5, 26 and 28 degrees are also considered.

Simulation results of tilt angle of 26 degree. In each simulation, monthly energy output, system losses, average irradiance etc. are evaluated.

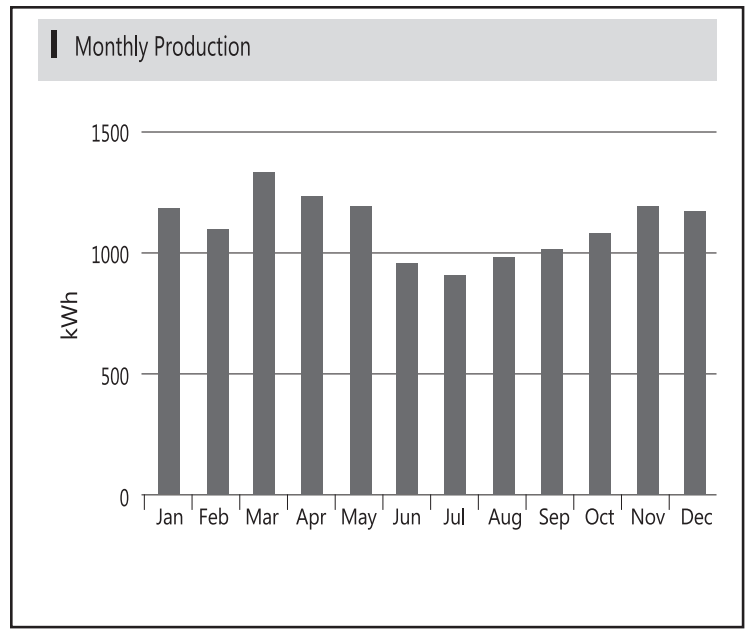

Fig. 2. Monthly Production of energy for tilt angle of 26 degrees 


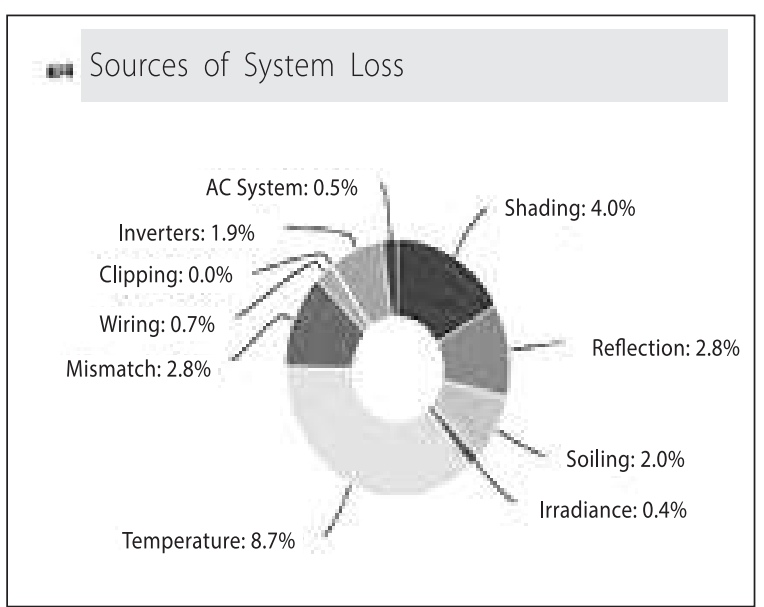

Fig. 3. Sources of system loss for 26-degree tilt angle

\begin{tabular}{|c|c|c|c|}
\hline \multicolumn{4}{|c|}{ - Annual Production } \\
\hline & Description & Output & \% Delta \\
\hline \multirow{6}{*}{$\begin{array}{l}\text { Irradiance } \\
\left(\mathrm{kWh} / \mathrm{m}^{2}\right)\end{array}$} & Annual Global Horizontal Irradiance & $1,771.1$ & \\
\hline & POA Irradiance & $1,941.5$ & $9.6 \%$ \\
\hline & Shaded Irradiance & $1,884.1$ & $-3.0 \%$ \\
\hline & Irradiance after Reflection & $1,831.0$ & $-2.8 \%$ \\
\hline & Irradiance after Soiling & $1,794.4$ & $-2.0 \%$ \\
\hline & Total Collector Irradiance & $1,794.4$ & $0.0 \%$ \\
\hline \multirow{8}{*}{$\begin{array}{l}\text { Energy } \\
\text { (kWh) }\end{array}$} & Nameplate & $15,690,041.3$ & \\
\hline & Output at Irradiance Levels & $15,629,618.7$ & $-0.4 \%$ \\
\hline & Output at Cell Temperature Derate & $14,256,570.5$ & $-8.8 \%$ \\
\hline & Output after Mismatch & $13,854,917.2$ & $-2.8 \%$ \\
\hline & Optimal DC Output & $13,762,565.3$ & $-0.7 \%$ \\
\hline & Constrained DC Output & $13,762,028.4$ & $0.0 \%$ \\
\hline & Inverter Output & $13,497,300.0$ & $-1.9 \%$ \\
\hline & Energy to Grid & $13,429,800.0$ & $-0.5 \%$ \\
\hline \multicolumn{4}{|c|}{ Temperature Metrics } \\
\hline & Avg. Operating Ambient Temp & & $27.8^{\circ} \mathrm{C}$ \\
\hline & Avg. Operating Cell Temp & & $39.0^{\circ} \mathrm{C}$ \\
\hline
\end{tabular}

Fig. 4. Annual production of Irradiance and Energy for 26-degree tilt angle

In order to make a comparative study, simulation has been done for a tilt angle of 23.5 degrees and the simulation results are shown in figure 5 \& 6 respectively.

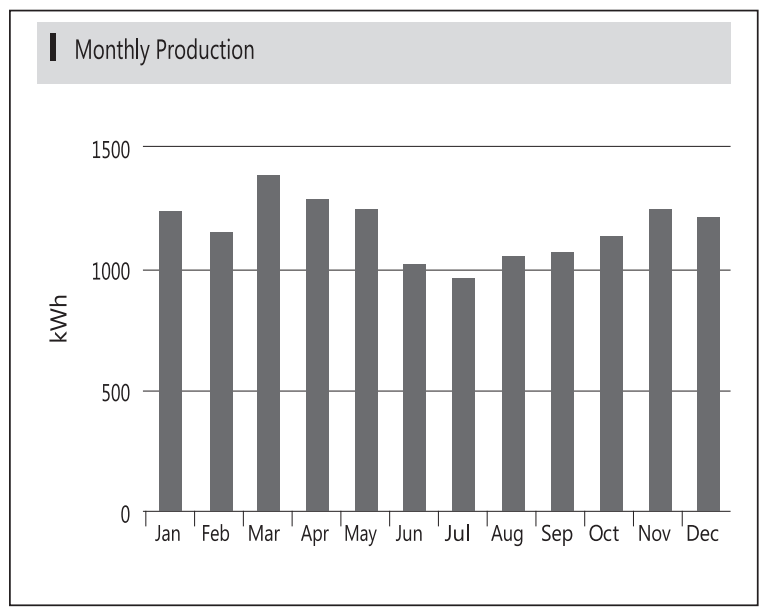

Fig. 5. Monthly Production of energy

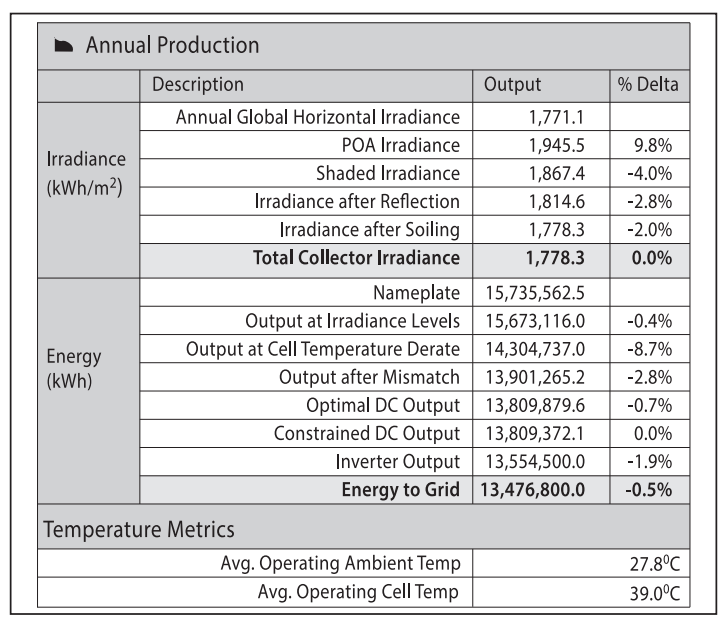

Fig. 6. Annual production of Irradiance and Energy for 23.5-degree tilt angle

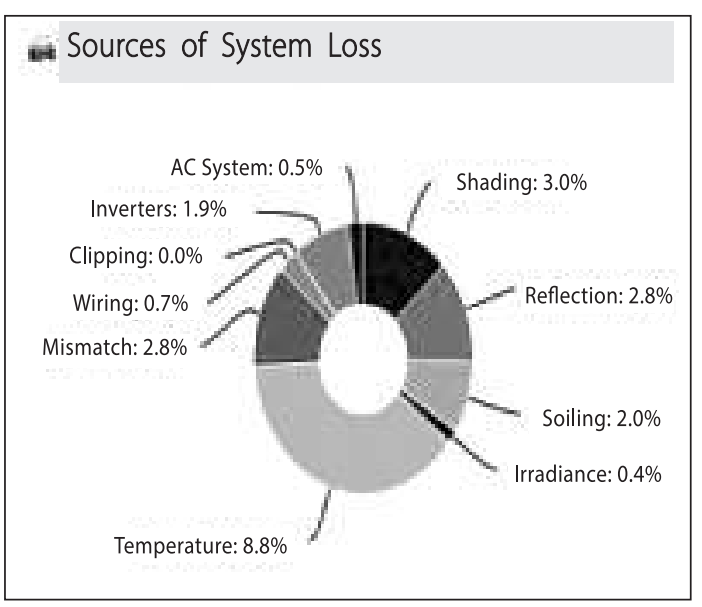

Fig. 7. Sources of system loss for 23.5-degree tilt angle

Fig. 7. Represents different system losses for a tilt angle of 23.5degree. In this figure, system losses like AC system inverters, clipping, wiring, Mismatch, Temperature, Irradiance, Soiling, Reflection, Shading are highlighted which is directly connected with solar PV output. For example, the losses of wiring are $0.7 \%$, Mismatch losses 2.8\%, Shading 3.0\%, Reflection $2.8 \%$, Soiling 2.0\%, AC System 0.5\%, Irradiance $0.4 \%$, Clipping $0.0 \%$ respectively. Here Clipping refers to the situation where the AC power output of an inverter is limited due to the peak rating of the inverter [8]. The major system losses for 23.5 and 26-degree tilt angles are shown in the following table.

\section{TABLE II}

System losses for different tilt angle (A comparative analysis)

\begin{tabular}{|l|l|l|}
\hline $\begin{array}{l}\text { Observation of tilt } \\
\text { angle }\end{array}$ & Shading & Temperature \\
\hline 23.5 & $3.0 \%$ & $8.8 \%$ \\
\hline 26 & $4.0 \%$ & $8.7 \%$ \\
\hline
\end{tabular}




\section{COMPARATIVE ANALYSIS OF OUTPUT WITH TILT ANGLE}

In this comparative analysis, we tried to give clear idea about enhanced energy and power generation together with optimum numbers of modules and inverters, and focusing on the overall performance ratio as well.

TABLE III

Comparative analysis of output with tilt angle

\begin{tabular}{|c|c|c|c|c|c|}
\hline $\begin{array}{l}\text { Obse } \\
\text { rvati } \\
\text { on of } \\
\text { tilt } \\
\text { angl } \\
\text { e }\end{array}$ & $\begin{array}{l}\text { Increase of } \\
\text { output } \\
\text { energy } \\
(\mathrm{KWh})\end{array}$ & $\begin{array}{l}\text { Increa } \\
\text { se of } \\
\text { output } \\
\text { power } \\
\text { (MW) }\end{array}$ & $\begin{array}{l}\text { Increase } \\
\text { in } \\
\text { Number } \\
\text { of } \\
\text { modules } \\
\text { required } \\
(320 \mathrm{~W})\end{array}$ & $\begin{array}{l}\text { Perfor } \\
\text { manc } \\
\text { e ratio } \\
\%\end{array}$ & $\begin{array}{l}\text { Increase } \\
\text { of } \\
\text { annual } \\
\text { producti } \\
\text { on } \\
\text { (GWh) }\end{array}$ \\
\hline $\begin{array}{l}23.5 \\
\text { (stan } \\
\text { dard) }\end{array}$ & $13,429,00$ & 8.61 & 26,906 & 80.3 & 13.43 \\
\hline $\begin{array}{l}23.5- \\
24.5\end{array}$ & $\begin{array}{l}13,333,200- \\
13,429,00 \\
=11,990,300\end{array}$ & $\begin{array}{l}8.65- \\
8.61=0 \\
.4\end{array}$ & $\begin{array}{l}27031- \\
26,906=1 \\
25\end{array}$ & $\begin{array}{l}80.5- \\
80.3=0 \\
.2\end{array}$ & $\begin{array}{l}13.49- \\
13.43=0.0 \\
6\end{array}$ \\
\hline $\begin{array}{l}23.5- \\
28\end{array}$ & $\begin{array}{l}13,488,400- \\
13,429,00=1 \\
2,145,500\end{array}$ & $\begin{array}{l}8.81- \\
8.61=0 \\
.2\end{array}$ & $\begin{array}{l}27522- \\
26,906=6 \\
16\end{array}$ & $\begin{array}{l}80.3- \\
79.4=0 \\
.9\end{array}$ & $\begin{array}{l}13.61- \\
13.43=0.1 \\
8\end{array}$ \\
\hline
\end{tabular}

The performance ratio is a measure of the quality of a PV plant that is independent of location and it therefore often described as a quality factor. The performance ratio (PR) is stated as percent and describes the relationship between the actual and theoretical energy outputs of the PV plant [9].

In our analysis we could clearly show that with the increase of tilt angle, the rate of energy, power, number of modules also increased. But the performance ratio with the variation of tilt angle from 22 to 28 degree reduced slightly because of increasing the tilt angle. However, this decrease in performance has got very little effect on the overall performance of the plant.

\section{CONCLUSION}

In this paper, the authors have tried to highlight the importance of reliable and cost effective design of a large solar PV based power plant through a tested and user friendly software like HolioScope. A large PV plant has been designed in the marshy land of Rajshahi district of Bangladesh with daily output capacity of around $7 \mathrm{MWp}$ under standard irradiation. Solar PV arrays with wiring and location of inverters, combiner box etc. are meticulously specified with average annual energy output and system losses. Also, the authors have tried to focus another important side of the designed PV plant that how does the output varies with the variation of the tilt angle. It has been found through simulation that the output variation is negligible with the increase of tilt angle. Rather increase of tilt angle reduces the space requirement which in turn provides more space for installation of extra solar panels. This enhances overall generation capacity of the plant which has been highlighted in the simulation results. Finally, increasing the tilt angle can produce sustainable impacts for the MW range solar PV grid being installed or to be installed in Bangladesh in terms of enhanced generation from such plants.

\section{REFERENCES}

[1] https://www.lrc.rpi.edu/programs/nlpip/lightingAnswers/phot ovoltaic/14-photovoltaic-tilt-angle.asp

[2] https://www.helioscope.com/exelsolar

[3] https://www.engineering.com/ElectronicsDesign/ElectronicsD esignArticles/ArticleID/7045/HelioScope-An-IntegratedPhotovoltaic-Design-Tool.aspx

[4] https://www.researchgate.net/publication/260532829 Effect of Tilt Angle Orientation on Photovoltaic Module Perfor mance

[5] Lewis, G., 1987. Optimum tilt of solar collector. Solar Wind Technol., 4: 407-410.

[6] Sterling, V.A., 2007. Planning and Installing Photovoltaic Systems: A Guide for Installers, Architects and Engineers. 2nd Edn.Earthscan Publications, London.

[7] Messenger, R.A. and J. Ventre, 2004. Photovoltaic System Engineers. CRC Press, Boca Raton.

[8] http://www.acsolarwarehouse.com/news/worried-aboutclipping-dont-be/

[9] http://files.sma.de/d1/7680/Perfratio-TI-en-11.pdf

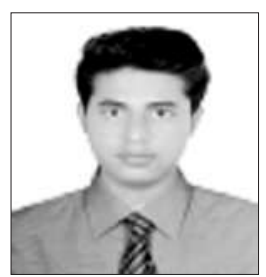

Md. Shahin Ali was born in Kushtia, Bangladesh in 1993. He received the BSc degree from the Department of Electrical and Electronic Engineering, Green University of Bangladesh, Dhaka, Bangladesh. $\mathrm{He}$ is currently working as a assistant engineer in Omera Renewable Energy Limited, Dhaka, Bangladesh. His research interests are in the areas of renewable energy, energy from renewable resources, prospects and challenges of solar home system in Bangladesh, solar grid designing, and rooftop PV system.

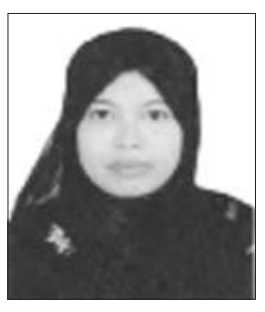

Nazmun Nahar Rima was born in Jessore, Bangladesh in 1995. She received BSc degree from the department of Electrical and Electronic Engineering, Green University of Bangladesh, Dhaka, Bangladesh. She is currently working as a research assistant at Green University of Bangladesh.Her research interest is in Renewable Energy from renewable resources, Solar grid designing, Solar 
home system in Bangladesh and rooftop PV system. She is a student of IEEE.

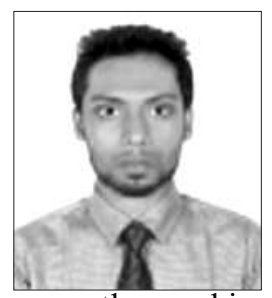

Md. Iftekhar Hossain Sakib was born in Noakhali, Bangladesh in 1993. He received the BSc degree from the Department of Electrical and Electronics Engineering, Green University of Bangladesh, Dhaka, Bangladesh. $\mathrm{He}$ is currently working as a Service Engineer in NAZ Corporation, Dhaka Bangladesh. His research interest is solar energy in the area of renewable energy.

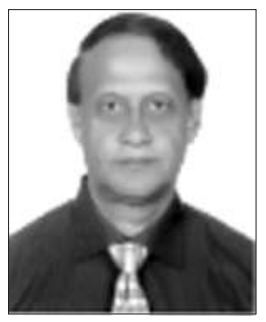

Md. Fayyaz Khan obtained his B.Sc. Degree in Electrical \& Electronic Engineering from BUET in 1974 and subsequently earned his Master's degree from BUET in 1977 on control systems. $\mathrm{He}$ did his Ph.D. from BUET in 2008 on electrical drives. Since after graduation from BUET, Dr. Khan served as lecturer in EEE from 1974 to 1977. In 1977, he was promoted to the rank of Assistant Professor in the EEE Department of BUET. From end of 1977 to 1990, he served in with different Ministries in Kuwait and Saudi Arabia. From 1990 to 1996, Dr. Khan served as a lecturer in the EEE department of University of Bahrain. In 1996, he came back to Bangladesh and served a number of private and international universities. He served IUT (under OIC), Gazipur, Ahsanullah University of Science \& Technology as Head of EEE department, University of Asia Pacific as Head of EEE \& CSE departments respectively and served as Head of EEE department of United International University, Dhaka. In 2017, he was appointed as Pro Vice Chancellor of Green University of Bangladesh. Presently, he is working as Professor of EEE department of Bangladesh
University of Business \& Technology (BUBT). Dr. Khan is deeply involved in research and consultancy work since after graduation from BUET. He has worked with different international companies in the power sector at home and abroad. He was a team member of a high powered team to look into the power crisis of Bangladesh. His research interests are: control systems, renewable energy, energy efficiency and electrical drives. Till to date, he is providing consultancy services in the renewable and energy efficiency sectors both nationally and internationally. 